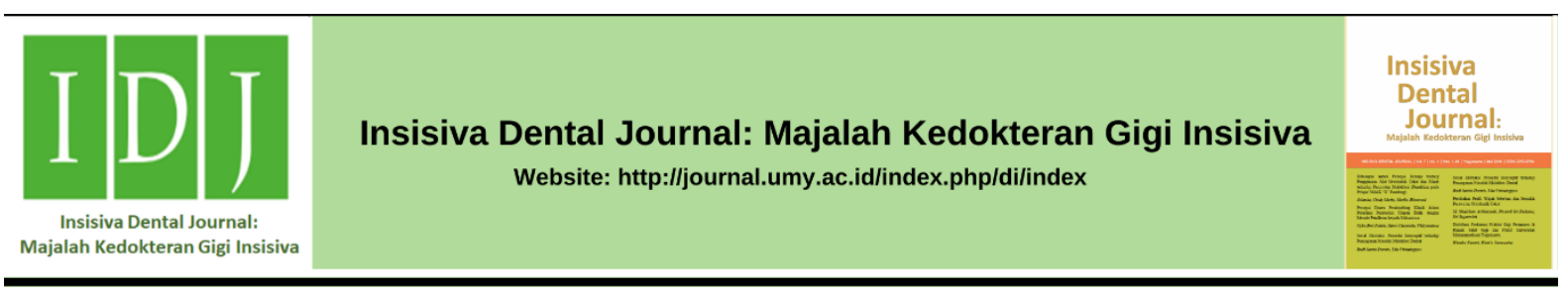

Research Article

\title{
Insidensi Ulkus Traumatikus pada Pemakai Alat Ortodonsi Lepasan dan Ortodonsi Cekat
}

Incidence of Traumatic Ulcer in Patient with Removable Orthodontic and Fixed Orthodontic Appliance

\section{Dwi Suhartiningtyas*, Novarini Prahastuti, Kharisma Sari}

Program Studi Kedokteran Gigi, Fakultas Kedokteran dan Ilmu Kesehatan, Universitas Muhammadiyah Yogyakarta, Jalan Brawijaya, Tamantirto, Kasihan, Bantul, Indonesia.

Received date: September $10^{\text {th }}, 2019$; reviewed date: October $16^{\text {th }}, 2019$; revised date: March $14^{\text {th }}, 2020$; accepted date: April $11^{\text {st }}, 2020$ DOI : 10.18196/di.9111

\begin{abstract}
Abstrak
Salah satu kelainan gigi mulut yang sering ditemukan adalah susunan gigi geligi yang tidak rapi. Alasan tersebut membuat masyarakat datang ke dokter gigi untuk melakukan perawatan ortodonsi dengan menggunakan alat lepasan (removable appliance) ataupun alat cekat (fixed appliance). Risiko pemakaian alat ortodonsi yang sering dilaporkan adalah ulkus traumatikus. Tujuan penelitian ini adalah untuk mengetahui insidensi ulkus traumatikus pada pemakai alat ortodonsi lepasan dan ortodonsi cekat. Jenis penelitian adalah penelitian observasional analitik dengan desain cohort prospective. Subjek penelitian adalah pasien di Rumah Sakit Gigi dan Mulut Universitas Muhammadiyah Yogyakarta dan di praktek dokter gigi spesialis ortodonsi yang akan melakukan insersi alat ortodonsi lepasan atau alat ortodonsi cekat. Subjek penelitian masing-masing kelompok berjumlah 21 orang yang memenuhi kriteria inklusi. Analisis data menggunakan uji statistik chi-square. Insidensi ulkus traumatikus pada pengguna alat ortodonsi lepasan sebanyak 12 kasus $(57,14 \%)$ dan pengguna alat ortodonsi cekat sebanyak 16 kasus $(76.19 \%)$. Hasil uji chi-square didapatkan nilai $\mathrm{p}=0,190(\mathrm{p}>0.05)$. Insidensi ulkus traumatikus pada pemakai alat ortodonsi cekat lebih tinggi dibandingkan pada pengguna alat ortodonsi lepasan, namun secara statistik tidak menunjukkan perbedaan bermakna.
\end{abstract}

Kata Kunci: Alat ortodonsi cekat; Alat ortodonsi lepasan; Ulkus traumatikus

\begin{abstract}
One of the oral dental abnormalities frequently found is the disarrangement of teeth. These reasons urge people to come to the dentist for orthodontic treatment using either a removable appliance or fixed appliance. The most commonly reported risk of using orthodontics appliance is traumatic ulcers. This article aims to determine the incidence of traumatic ulcers in patients with removable orthodontic and fixed orthodontic appliances. This research is an observational analytic with a prospective cohort design. Subjects were patients at the Dental Hospital of Universitas Muhammadiyah Yogyakarta and in the practice of orthodontic specialists who would implement removable or fixed orthodontic appliances. The research subjects of each group were 21 people who met the inclusion criteria. Data analysis used the chi-square test. The incidence of traumatic ulcers in patients with the removable orthodontic appliance was 12 cases $(57.14 \%)$, while patients with the fixed orthodontic appliance were 16 cases $(76.19 \%)$. Chi-square test results obtained $p=0.190(p>0.05)$. The incidence of traumatic ulcers in patients with the fixed orthodontic appliance is higher than in patients with the removable orthodontic appliance. However, it does not statistically show significant differences.
\end{abstract}

Keywords: Fixed orthodontics appliance; Removable orthodontic appliance; Traumatic ulcer

*Corresponding author, e-mail: wiwik_baby@yahoo.com 


\section{PENDAHULUAN}

Maloklusi merupakan salah satu masalah kesehatan gigi dan mulut yang dapat mempengaruhi penampilan wajah (estetika) dan status sosial pasien. Penelitian epidemiologis menunjukkan bahwa setidaknya $70 \%$ dari populasi mengalami maloklusi. Memperbaiki penampilan wajah merupakan salah satu alasan pasien datang ke dokter gigi untuk mendapatkan perawatan ortodonsi. ${ }^{1}$ Perawatan ortodonsi merupakan perawatan bertujuan untuk membentuk struktur wajah dan memperbaiki susunan gigi geligi yang tidak rapi atau maloklusi. ${ }^{2}$

Berdasarkan cara pemakaiannya, alat ortodonsi dibedakan menjadi dua yaitu alat ortodonsi lepasan (removable orthodontic appliance) dan alat ortodonsi cekat (fixed orthodontic appliance). Sejumlah piranti pada alat ortodonsi lepasan antara lain plat akrilik yang dilengkapi clasps dan spring serta labial arch, sedangkan pada alat ortodonsi cekat terdiri dari band, bracket dan wire. $^{3}$ Pemakaian alat ortodonsi selain mempunyai fungsi yang sangat bermanfaat bagi mulut namun juga mempunyai kekurangan, yaitu dapat menyebabkan kerusakan fisik pada mukosa mulut. Iritasi akibat komponen alat ortodonsi seperti klamer, permukaan plat kasar dengan tepitepi yang tajam, menyebabkan kerusakan jaringan (ulserasi) pada mukosa mulut. ${ }^{4}$ Pemakaian alat ortodonsi memiliki risiko terjadinya ulkus traumatikus, masalah pada sendi temporomandibula dan masalah pada jaringan periodontal. $^{5}$

Ulkus traumatikus akut dapat terjadi dalam waktu kurang dari tiga minggu, sedangkan ulkus traumatikus kronis terjadi dalam kurun waktu lebih dari tiga minggu. Faktor yang dapat memicu terjadinya ulkus traumatikus adalah akibat tepi-tepi insisal maupun oklusal gigi yang tajam, keadaan restorasi kurang pas dan pemakaian alat ortodonsi yang kurang tepat. ${ }^{6}$ Penelitian sebelumnya melaporkan ulkus traumatikus yang terjadi pada pasien dengan alat ortodonsi cekat paling sering diakibatkan oleh kawat/wire yang terlalu panjang, ${ }^{7}$ sedangkan pada pasien dengan alat ortodonsi lepasan akibat tekanan berlebihan dari alat dan plat dasar yang digunakan sebagai basis memiliki struktur kasar, tepi alat tidak pas dan tajam. ${ }^{8}$ Tujuan penelitian ini adalah untuk mengetahui insidensi ulkus traumatikus pada pemakai alat ortodonsi lepasan dan ortodonsi cekat.

\section{MATERIAL DAN METODE}

Penelitian ini telah dilakukan pada Januari - Maret 2018, bertempat di Rumah Sakit Gigi dan Mulut Universitas Muhammadiyah Yogyakarta (RSGM UMY) dan praktek dokter gigi spesialis ortodonsi menggunakan desain observasional analitik dengan pendekatan cohort prospective. Subyek penelitian terdiri dari pasien-pasien yang akan insersi alat ortodonsi yang memenuhi kriteria inklusi, berjumlah 42 pasien yang dipilih menggunakan metode total sampling. Kriteria inklusi meliputi pasien yang akan insersi alat ortodonsi rahang atas dan rahang bawah, usia 12 sampai 30 tahun, tidak memiliki penyakit sistemik dan besedia ikut serta dalam penelitian. Prosedur pengumpulan data dilakukan sejak hari pertama setelah pasien insersi alat sampai hari ke-90. Pasien yang mengalami ulkus traumatikus, melaporkan ke peneliti kemudian dilakukan anamnesis dan pemeriksaan lesi. Data yang diperoleh, dicatat dan kemudian dianalisis dengan uji chi-Square.

\section{HASIL}

Penelitian tentang insidensi ulkus traumatikus pada pemakai alat ortodonsi lepasan dan ortodonsi cekat telah dilakukan. Subjek yang memenuhi kriteria sebanyak 42 orang, masing-masing kelompok terdiri 21 orang. Insidensi ulkus traumatikus diamati sejak alat ortodonsi digunakan pertama kali sampai tiga bulan pemakaian. Karakteristik subjek penelitian berdasarkan jenis kelamin dan usia tersaji seperti pada Tabel 1 . 
Tabel 1. Karakteristik subjek penelitian berdasarkan jenis kelamin dan usia

\begin{tabular}{lcccc}
\hline Variabel & n (Alat Lepasan) & \% & n ( Alat Cekat ) & $\%$ \\
\hline Jenis kelamin & & & & \\
Laki-laki & 8 & 38,09 & 6 & 28,57 \\
Perempuan & 13 & 61,91 & 15 & 71,43 \\
Usia & 2 & & & 57,15 \\
$<20$ tahun & 19 & 9,52 & 12 & 33,33 \\
$20-25$ tahun & 0 & 90,48 & 7 & 9,52 \\
$>25$ tahun & 21 & 0 & 2 & 100 \\
Total & & 100 & 21 & \\
\hline
\end{tabular}

Tabel 2. Insidensi ulkus traumatikus berdasarkan waktu terjadinya

\begin{tabular}{lcccccccc}
\hline \multirow{2}{*}{ Insidensi } & \multicolumn{2}{c}{ Minggu Ke 1 } & \multicolumn{2}{c}{ Minggu Ke 2-4 } & \multicolumn{2}{c}{ Minggu Ke 5-12 } & \multicolumn{2}{c}{ Total } \\
\cline { 2 - 9 } Jenis Alat & $\mathbf{n}$ & $\mathbf{\%}$ & $\mathbf{n}$ & $\mathbf{\%}$ & $\mathbf{n}$ & $\mathbf{\%}$ & $\mathbf{n}$ & \% \\
\hline Alat lepasan & 6 & 28,57 & 3 & 14,28 & 3 & 14,28 & 12 & 57,13 \\
Alat cekat & 13 & 61,90 & 3 & 14,28 & 0 & 0 & 16 & 76,18 \\
\hline
\end{tabular}

Tabel 3. Hasil uji chi-square insidensi ulkus traumatikus

\begin{tabular}{lcccccc}
\hline Ulkus Traumatikus & \multicolumn{2}{c}{ Ya } & \multicolumn{2}{c}{ Tidak } & \multicolumn{2}{c}{ Nilai P } \\
Jenis Alat & n & \% & n & \% & \\
\hline Alat lepasan & 12 & 57,14 & 9 & 42,86 & 0.190 \\
Alat cekat & 16 & 76,19 & 5 & 23,80 & \\
\hline
\end{tabular}

Pengamatan selanjutnya adalah terkait insidensi ulkus traumatikus yang diikuti mulai minggu pertama setelah pemakaian alat hingga minggu ke-12. Hasil pengamatan insidensi ulkus traumatikus berdasarkan waktu terjadinya dapat dilihat pada Tabel 2. Hasil uji statistik pada kedua kelompok dengan chi-square test dapat dilihat pada Tabel 3 .

\section{PEMBAHASAN}

Estetika wajah merupakan masalah penting dalam kehidupan sosial saat ini. Berbagai bentuk maloklusi dapat mempengaruhi kepercayaan diri pasien karena memiliki pengaruh buruk pada kualitas hidup dan interaksi sosial individu. Berdasarkan alasan tersebut, sebagian besar pasien mencari perawatan ortodontik untuk meningkatkan estetika wajah. ${ }^{9}$

Saat ini penggunaan alat ortodonsi makin banyak diminati oleh masyarakat terutama pada kalangan remaja dan dewasa muda, sebagai upaya untuk meningkatkan persepsi diri, harga diri, dan kepercayaan diri sehingga mempengaruhi kualitas hidup dan interaksi sosial. ${ }^{10}$ Perempuan merupakan individu yang sangat peduli dengan keindahan, tidak terkecuali dalam penggunaan alat ortodonsi. Seperti halnya pada penelitian ini (Tabel 1), menunjukkan bahwa responden yang menggunakan alat ortodonsi cekat maupun lepasan didominasi pasien perempuan. Perempuan cenderung lebih memperhatikan fashion dan penampilan dibandingkan laki-laki terutama dari segi estetika wajah. ${ }^{11}$

Karakteristik selanjutnya yang dapat dilihat pada Tabel 1 adalah rentang usia pengguna alat ortodonsi. Usia merupakan salah satu faktor yang berpengaruh dalam keberhasilan perawatan ortodonsi. Perawatan ortodonsi lebih efektif dilakukan pada usia muda (dibawah 21 tahun), karena pada saat itu pergerakan gigi membutuhkan proses resorpsi dan aposisi tulang alveolar oleh sel osteoblas dan osteoklas. Proses pembentukan sel osteoblas dan osteoklas pada usia muda berlangsung lebih aktif sehingga akan didapatkan kemajuan perawatan yang optimal. ${ }^{12}$ Penelitian serupa menyebutkan bahwa penggunaan alat ortodonsi didominasi kalangan remaja dengan alasan sering merasa tidak puas dengan penampilan wajahnya. Dengan perawatan ortodonsi diharap dapat memperbaiki 
susunan gigi geligi menjadi lebih rapi untuk menambah estetika yang dimilikinya. ${ }^{13}$

Rata-rata seseorang memiliki riwayat maloklusi sehingga perlu melakukan perawatan ortodonsi adalah pada usia 16-17 tahun. ${ }^{14}$ Hasil penelitian ini berbeda dengan penelitian - penelitian sebelumnya, dimana rata-rata usia pasien yang melakukan perawatan ortodonsi adalah pasien dewasa (20-25 tahun). Hal ini kemungkinan pada usia tersebut, banyak orang dewasa (usia >20 tahun) sudah melewatkan usia anak dan remaja tanpa sempat melakukan perawatan ortodonti untuk memperbaiki susunan gigi yang kurang baik. Selain itu, pada saat usia anak dan remaja, mungkin perkembangan perawatan ortodonsi saat itu tidak sepesat saat ini.

Hasil pengamatan insidensi ulkus traumatikus berdasarkan waktu terjadinya (Tabel 2), temuan ulkus traumatikus pada minggu pertama lebih banyak bila dibandingkan dengan minggu-minggu selanjutnya untuk kedua kelompok. Hal ini dimungkinkan karena pada awal-awal penggunaan alat ortodonsi pasien masih dalam tahap penyesuaian atau adaptasi terhadap penggunaan alat di rongga mulut. Munculnya berbagai keluhan pada awal pemakaian merupakan hal yang wajar. Pada masa adaptasi, komponen alat ortodonsi yang umumnya memiliki bagian tajam dapat mengiritasi mukosa mulut sehingga sangat berisiko untuk terjadinya ulkus traumatikus. Penelitian ini sesuai dengan penelitian sebelumnya yang menyatakan bahwa lesi ulserasi pada jaringan lunak dimulai pada hari pertama hingga hari ketujuh. Selain adanya ulkus, hal yang sering dikeluhkan adalah adanya rasa nyeri. ${ }^{15}$

Hal lain yang mendasari sering terjadinya ulkus traumatikus pada awal penggunaan alat ortodonsi adalah pada periode awal keadaan gigi geligi yang akan dikoreksi masih mengalami malposisi sehingga apabila komponen alat ortodontik ditempatkan pada area tersebut dapat berisiko menyebabkan terjadinya ulkus traumatik. $^{7}$

Hasil analisis data yang ditunjukkan pada Tabel 3, menunjukkan nilai signifikansi $\mathrm{p}=0,190(\mathrm{p}>0,05)$. Hal tersebut menandakan bahwa insidensi ulkus traumatikus pada pengguna alat ortodonsi lepasan maupun cekat tidak terdapat perbedaan bermakna secara statistik. Artinya risiko dan komplikasi yang dapat dialami oleh pasien dengan alat ortodonsi lepasan dan cekat sama besarnya terutama pada tahap awal pemakaian. ${ }^{15}$ Seiring berjalannya waktu, risiko terjadinya ulkus traumatikus pada kedua kelompok juga menurun, karena proses adaptasi mukosa yang sudah berjalan baik. Ulkus traumatikus merupakan lesi yang terbentuk oleh kerusakan lokal dari jaringan epitelium akibat trauma fisik, termal, maupun kimiawi. Penggunaan alat ortodontik (lepasan atau cekat) termasuk salah satu faktor fisik yang dapat menyebabkan ulkus traumatik. Komponen - komponen alat yang tajam, pembuatan alat yang kurang baik, dan keterampilan pasien dalam memasang alat ortodonsi lepasan yang digunakan merupakan faktor yang dapat menyebabkan trauma pada mukosa mulut.

\section{KESIMPULAN}

Insidensi ulkus traumatikus pada pasien dengan alat ortodonsi cekat sebanyak 16 orang $(76,19 \%)$ dan pada pasien dengan alat ortodonsi lepasan sebanyak 12 orang $(57,14 \%)$. Secara statistik tidak ada perbedaan bermakna antara kedua kelompok.

\section{DAFTAR PUSTAKA}

1. Sharma S, Narkhede S, Sonawane S, Gangurde P. Evaluation of Patient's Personal Reasons and Experience with Orthodontic Treatment. J Int oral Health . 2013; 5(6): 78-81.

2. Mainali A. Occurrence of Oral Ulcerations in Patients undergoing Orthodontic Treatment: A Comparative study. Orthod J Nepal. 2014; 3(2):32-35. 
3. Baricevic M, Mravak-Stipetic M, Majstorovic M, Baranovic M, Baricevic D, Loncar B. Oral mucosal lesions during orthodontic treatment. Int J Paediatr Dent. 2011; 21(2): 96102.

4. Alam M.K. Alam, A to Z Orthodontics. Volume 10: Removable Orthodontic Appliance. Malaysia: PPSP Publication. 2014.

5. Karanprakash Singh AG. Assessment of Oral Health Problems in Patients Receiving Orthodontic Treatment. Dentistry. 2015; 5(2): 5-7.

6. Ariyawardana A. Traumatic Oral Mucosal Lesions : A Mini Review and Clinical Update. Oral Health Dent Manag. 2014; 13(2): 254-259.

7. Manoppo, S. K. P. Gambaran ulkus traumatik pada mahasiswa pengguna alat ortodontik cekat di Program Studi Kedokteran Gigi Fakultas Kedokteran Universitas Sam Ratulangi. e-GIGI. 2013; 1(2): 1-9.

8. Kunsputri, F. A., \& Suhartiningtyas, D. Prevalensi stomatitis traumatik pemakai alat ortodonsi lepasan (kajian di rumah sakit gigi dan mulut pendidikan asri medical center Yogyakarta). Insisiva Dental Journal: Majalah Kedokteran Gigi Insisiva, 2013; 2(1): 57-62.

9. Kaur, S., Singh, R., Soni, S., Garg, V., \& Kaur, M. (2018). Esthetic orthodontic appliances-A review. Ann Geriatr Educ Med Sci, 2018; 5(1): 11-14.

10. Heravi, F., Ahrari, F., Rashed, R., Heravi, P., Ghaffari, N., \& Habibirad,
A. Evaluation of factors affecting dental esthetics in patients seeking orthodontic treatment. Int J Orthod Rehabil, 2016; 7(3): 79-84.

11. Irwansyah M, Erwansyah E. Penilaian tingkat keberhasilan perawatan ortodontik dengan piranti lepasan berdasarkan indeks PAR Assessment of success rate of orthodontic treatment using removable appliance based on PAR index. J Dentomaxillofacial Sci. 2011; 10(3): 144-150.

12. Vania, E., Zenab, Y., \& Sunaryo, I. R. Kemajuan perawatan ortodontik dengan sekrup ekspansi rahang atas pada crowding ringan Orthodontic treatment progress of mild crowding with maxillary expansion screws. $J$ Ked Gig, 2016; 28(2): 113-118.

13. Herwanda, H., Arifin, R., \& Lindawati, L. Pengetahuan Remaja Usia 15-17 Tahun di SMAN 4 Kota Banda Acehterhadap Efek Samping Pemakaian Alat Ortodonti Cekat. J Syiah Kuala Dent Soc. 2016; 1(1): 7984.

14. Rorong, G. F., \& Pangemanan, D. H. (2016). Gambaran maloklulsi pada siswa kelas 10 di SMA Negeri 9 Manado. e-GIGI. 2016; 4(1): 1-7.

15. Kavaliauskiene, A., Smailiene, D., Buskiene, I., \& Keriene, D. Pain and discomfort perception among patients undergoing orthodontic treatment: results from one month follow-up study. Stomatologija, 2012; 14(4), 118-125. 